\title{
KOMPARATYSTYKA NA POGRANICZU DZIEDZIN
}

Violetta Julkowska

\section{ABSTRACT}

\section{COMPARATISTICS ON THE BORDER OF FIELDS}

The purpose of the article is to show comparatistics as a promising perspective of current humanistic research, especially in area of extending possibilities of analysis and interpretation. In times of profesionalization and specialization of knowledge, comparative research are rarely undertaken and for that reason, it makes a cognitively and interpretatively interesting situation. The case analysis applies to using comparative method on the ground of history of historiography (A. Kożuchowski) and literary studies (D. Zawadzka).

\section{KEYWORDS:}




\section{WPROWADZENIE}

Celem niniejszego artykułu jest przybliżenie badań porównawczych, powstających w kręgu historii historiografii oraz literaturoznawstwa, które z racji sposobu konceptualizacji tematu oraz prowadzenia analizy z użyciem metody paraleli budzą moje zainteresowanie. Szczególnie interesujące są badania prowadzone na pograniczu dyscyplin: historii historiografii, historii literatury oraz krytyki literackiej!

W dobie profesjonalizacji i specjalizacji wiedzy tego typu interdyscyplinarne badania porównawcze podejmowane są rzadko ze względu na ich złożony charakter, dlatego tworzą ciekawą poznawczo i interpretacyjnie sytuację. Ujęcie paralelne poczynione na granicy dziedzin otwiera bowiem pracę analityczną i interpretacyjną na cały szereg pytań, w tym o tożsamość każdej z badanych dziedzin. Jednocześnie rodzi się inne pytanie o to jakie są konsekwencje wykorzystania w macierzystym polu badawczym literaturoznawstwa strategii i metod specyficznych dla pola badań historiografii. Zakładając, że powstanie nowoczesnych dyscyplin dokonywało się jako proces stopniowego zamykania ich pól badawczych i interpretacyjnych, interesująca jest odpowiedź na pytanie, w jaki sposób uzasadniane jest współcześnie przekroczenie granicy tych autonomicznych pól, a także w jaki sposób kapitał symboliczny każdej z dyscyplin (literaturoznawstwa i historii historiografii) wnoszony do innego pola badań, wpływa na odczytanie i interpretację porównawczą tekstów, które zostały przywołane w badaniach, a które pochodzą z obu pól badawczych. Pojęcie kapitału symbolicznego, pochodzące z kręgu studiów kulturowych P. Bourdieu, zaaplikowane zostało tu w znaczeniu oryginalnym, a mianowicie odnosi się do problemu ochrony własnego pola badawczego w sytuacji otwarcia własnej dyscypliny na wpływy zewnętrzne. Badanie na pograniczu dyscyplin nie prowadzi zdaniem Bourdieu do przyjęcia logiki innego pola badawczego, o ile zachowana zostaje świadomość własnego kapitału symbolicznego 2 .

W analizowanym przypadku na kapitał symboliczny składają się: po pierwsze adekwatne kompetencje warsztatowe i metodologiczne, po drugie język komunikacji właściwy dla danej dyscypliny badawczej, po trzecie tzw. wyczucie gry, oznaczające tutaj znajomość współczesnych przemian w obszarze dyscyplin pokrewnych oraz znajomość ich szerokiego kontekstu historycznego. W zarysowanej sytuacji poznawczej pojawia się pytanie o to, co postrzegane jest jako wspólne/różne w podejściu badawczym historyka historiografii i literaturoznawcy w obliczu raz tekstu stricte historycznego, a innym razem w przypadku tekstu dyskursywnego.

Przedmiotem analizy i refleksji w niniejszym tekście są paralela historiograficzno-literacka Danuty Zawadzkiej (Lelewel i Mickiewicz. Paralela, Białystok 2013) oraz paralela historiograficzna Adama Kożuchowskiego (Powinowactwa mimo woli. Święte Cesarstwo Rzymskie Narodu Niemieckiego i Rzeczpospolita Obojga Narodów w niemieckiej i polskiej historiografii XIX wieku, Warszawa 2016).

P. Bourdieu, Reguly sztuki. Geneza i struktura pola literackiego, Kraków 2001. 


\section{KOMPARATYSTYKA WE WSPÓ ŁCZESNYCH BADANIACH HUMANISTYCZNYCH}

Filozofia porównywania posiada głęboko antyczny rodowód, związany z grecką synkrisis, a więc stosowaną na gruncie retoryki strategią porównawczego ukazywania postaci lub rzeczy z zamiarem ich przeciwstawienia, ale również z ideą agonu, opartą na rywalizacji w odmienności. W obu przypadkach porównanie nie ogranicza się do prostego zestawienia porównawczego, lecz towarzyszy mu określona gra nastawiona na uzyskanie nowych znaczeń. Korzenie starożytne posiada również rodzaj comparandum w postaci zasad greckiej estetyki, swoiste pole odniesienia, które do końca XVIII wieku wyznaczało kulturze europejskiej wspólny kontekst komunikacyjny. Pamiętamy także, że u początków praktyki dziejopisarskiej, a zarazem biograficznej, pojawiło się dzieło oparte na zestawieniu porównawczym, czyli Plutarcha Żywoty sławnych mężów, uważane współcześnie za początek takich wielkich nurtów porównawczych jak badania nad wpływem i recepcją ${ }^{3}$. Pomimo postępującego w XIX wieku procesu fragmentaryzacji i autonomizacji humanistyki, tworzącej samodzielne dyscypliny badawcze, nadal trwała wspólnota kulturowa mająca swe źródła w klasycznym wykształceniu, tworząc silne pole symboliczne, które umożliwiało porozumiewanie się. Tą swoistą wielopokoleniową universitas podtrzymywał wspólny model edukacji, funkcjonujący na gruncie europejskim aż do początków XX wieku dzięki klasycznemu gimnazjum. W ramach tej wspólnoty kulturowej klasyczny wykład metody porównawczej wyszedł poza wiek XVIII, pojawiając się w powstających na początku XIX wieku historykach, już jako metoda historyczna, chociaż zaczerpnięta $\mathrm{z}$ tradycji poetyk antycznych ${ }^{4}$.

Współcześni metodolodzy uważają, że podstawowym bodźcem dla rozwoju badań komparatystycznych w humanistyce, w ich nowożytnym kształcie, był przełom romantyczny i rozwijający się na początku XIX wieku kult indywidualizmu ${ }^{5}$. Filologiczny rodowód komparatystyki gwarantował rzetelne obchodzenie się z tekstem, który jest podstawowym przedmiotem zainteresowania komparatystów, jednak warsztaty literaturoznawców i historyków, mające początkowo wspólne korzenie filologiczne, zaczęły na początku XX wieku wyraźnie się różnicować.

Strukturalistyczny i postrukturalistyczny warsztat historyków literatury i literaturoznawców, nadal posiada grunt w postaci kompetencji analitycznych o charakterze filologicznym, ale zarazem oswaja z aktualnymi kontekstami kulturowymi

Por.: E. Kasperski, Kategorie komparatystyki, Warszawa 2010.

Por.: Niewspótmierność. Perspektywy nowoczesnej komparatystyki. Antologia. Red. T. Bilczewski, Kraków 2010.

Por.: Komparatystyka dzisiaj. Problemy teoretyczne, t.1, red. E. Szczęsna, E. Kasperski, Kraków 2010; Komparatystyka dzisiaj. Interpretacje, t.2, red. E. Kasperski, E. Szczęsna, Kraków 2011; Kasperski, U podstaw komparatystyki, [w:] Komparatystyka dla humanistów, red. M. Dąbrowski. Warszawa 2011. 
w obszarze interpretacji. W przypadku badań historycznych i historiograficznych obie kompetencje: warsztatowa i metodologiczna/teoriopoznawcza, bywają postrzegane rozłącznie. Prawdopodobnie z tego powodu metoda porównawcza zadomowiła się w dużo większym stopniu wśród literaturoznawców, natomiast na gruncie historiografii częściej spotykana jest jako rodzaj konceptualizacji badań stricte historycznych, czego przykładem są klasyczne biografie równoległe czy znakomita praca Timothy Snydera ${ }^{6}$.

Są jednak obszary historii historiografii szczególnie podatne na stosowanie metody porównawczej. Mam na myśli różne ujęcia syntez powszechnodziejowych, w których porównywane są dzieje poszczególnych narodów ${ }^{7}$.

Współcześnie trwa poszukiwanie adekwatnego modelu historii transnarodowej, który odchodząc od ujęć klasycznych tworzyłby nową, transnarodową perspektywę porównawczą ${ }^{8}$.

Zarysowane powyżej problemy ulegają nasileniu w przypadku poszukiwania modelu badań porównawczych, które prowadzone są na pograniczu pokrewnych dziedzin humanistyki. Wynikają one z konieczności wnoszenia na poszczególne pola badawcze odmiennych kompetencji, reguł i języka dyskursu właściwego dla dyscyplin coraz bardziej rozłącznych, wcześniej koegzystujących bądź traktowanych do końca XIX wieku w pracach syntetycznych jako całość dorobku piśmiennictwa historycznego ${ }^{9}$.

Rosnąca autonomia dyscyplin prowokuje współczesnych komparatystów do stawiania pytań o zasadność tak daleko posuniętej specjalizacji i rozłączności obszarów badań humanistyki. Prowadzi to w konsekwencji do prób poszukiwania nowego uniwersum w ramach konceptów teoretycznych i podejmowanych strategii badawczych, a więc na poziomie metahistorycznym i metakrytycznym w ramach zróżnicowanego nurtu badań historii kultury ${ }^{10}$. Podejście to umożliwia ustalenie relacji ogólnych pomiędzy poszczególnymi dziedzinami wiedzy humanistycznej, koncentrując się na ich cechach konstytutywnych w danych obszarach paradygmatycznych.

Komparatystyka jest dla współczesnej humanistyki sposobem zdystansowanego, dialogicznego podejścia do problematyki analizy i interpretacji zbiorowych dyskursów tożsamościowych, zwłaszcza sprawdziła się w jednej z odmian tego dyskursu jaką przyniósł nurt pamięcioznawczy. Zapoczątkowany w obszarze badań nad tożsamością kulturową Francuzów przez P. Nora, kontynuowany jest z powodzeniem

\footnotetext{
Por.: T. D. Snyder, Skrwawione ziemie. Europa między Hitlerem a Stalinem, Warszawa 2015.

Por.: Metodologiczne problemy syntezy historii historiografii polskiej, red. J. Maternicki, Rzeszów 1998.

Por.: J. Pomorski, W poszukiwaniu modelu historii transnarodowej - przypadek Timothy'ego Snydera, [w: ] Tegoż, Spoglądając w przeszłość, Lublin 2017.

9 Por.: V. Julkowska, Historia dla wyobraźni. Recepcja i interpretacja piśmiennictwa historycznego Karola Szajnochy, Poznań 2010.

10 Por.: H. Markiewicz, Historia a literatura, „Pamiętnik Literacki” 2006, z. 3.
} 
na poziomie uhistorycznionych badań porównawczych, obejmujących zbiorowe imaginaria różnych narodów i wspólnot sąsiedzkich. Przykładem udanego włączenia komparatystyki do obszaru badań nad recepcją i pamięcią jest seria prac poświęconych polsko-niemieckim miejscom pamięci, ale także współczesne badania prowadzone w obszarze nowej regionalistyki ${ }^{11}$.

Na poziomie egzemplifikacji gatunkowej komparatystyka przybiera różne oblicza, poczynając od prostych ujęć porównawczych o charakterze analogii lub antynomii, jak miało i ma to miejsce w przypadku żywotów równoległych. Pojawiają się również złożone paralele synchroniczno-diachroniczne, obejmujące nie tylko wielkie postaci i państwa, ale i wielowymiarowe struktury problemowe ${ }^{12}$.

Rozpatrywany w tekście przypadek paraleli posiada dwie odsłony. Pierwszą stricte historiograficzną, przywołaną jako przykład współczesnej próby zastosowania metod komparatystycznych w obszarze historii historiografii dla wzbogacenia możliwości interpretacji. Drugą z pogranicza dyscyplin pokrewnych, która podejmuje problem pojawienia się nowych perspektyw poznawczych i interpretacyjnych, gdy historia historiografii i literaturoznawstwo potraktowane zostaną komplementarnie, jako rodzaj autorefleksji uprawianej na pograniczu dziedzin, a nie tylko w obrębie własnej dyscypliny głównej, czyli osobno historii i literatury.

W pierwszym przypadku paralela jest rodzajem konceptu zastosowanego dla ukazania „mimowolnego powinowactwa” dwóch równolegle tworzonych przez historiografię obrazów państwa na przestrzeni wieków. W drugim przypadku paralela jest konsekwentnie zastosowaną metodą komparatystyczną w celu wzajemnego odczytania sensów niesionych przez teksty historyczne dwóch współczesnych sobie i pozostających w napięciu dialogicznym twórców wizji historycznych i historiozoficznych.

\section{W KRĘGU PARALELI Z OBSZARU HISTORII HISTORIOGRAFII}

Analizę przypadku rozpocznę od współczesnej paraleli stricte historiograficznej jaką jest praca Adama Kożuchowskiego Powinowactwa mimo woli. Święte Cesarstwo Rzymskie Narodu Niemieckiego i Rzeczpospolita Obojga Narodów w niemieckiej i polskiej historiografii XIX wieku ${ }^{13}$. Jej autor zastrzega na wstępie, że nie jest to paralela historyczna typu Lelewelowskiego, czyli polegająca na poszukiwaniu wspólnego modelu rozwo-

\footnotetext{
Modi memorandi. Leksykon kultury pamięci, red. M. Saryusz-Wolska, R. Traba, Warszawa 2014. Por.: K. Górski, Mickiewicz-Lelewel, Torun 1986.

13 A. Kożuchowski, Powinowactwa mimo woli. Święte Cesarstwo Rzymskie Narodu Niemieckiego i Rzeczpospolita Obojga Narodów w niemieckiej i polskiej historiografii XIX wieku, Warszawa 2016.
} 
jowego w dziejach Polski i Niemiec, tak jak uczynił to historyk w Historycznej paraleli Hiszpanii z Polską ${ }^{14}$. Oznacza to, że autor rezygnuje z ukazania paraleli historycznej pierwszego stopnia, chcąc przedmiotem swojego badania uczynić obraz dziejów Polski i Niemiec w ujęciu historyków. Zatem paralela Kożuchowskiego zamierzona została znacznie ambitniej, jako „obraz tych dziejów w historiografii obu narodów”, będący dziełem historyków dziewiętnastowiecznych, piszących w Polsce i w Niemczech ${ }^{15}$. W szerokiej reprezentacji prac historiograficznych zaprezentowanych przez autora tytułowe „mimowolne powinowactwo” jest świadomym, autorskim konceptem konstruującym całość pracy. Paralela polsko-niemiecka czyni z niej pracę pionierską na gruncie polskim, chociaż podobna problematyka była już podejmowana wcześniej i na mniejszą skalę przez historyków niemieckich Hansa J. Bümelburga i Michaela Müllera.

Pod względem metodologicznym praca Kożuchowskiego ma charakter studium interpretacyjnego w obszarze historii historiografii, buduje bowiem sensy znaczeniowe w oparciu o analizę obrazu dziejów zawartą w obu historiach narodowych, przeprowadzając rozpoznanie na licznej grupie autorów reprezentatywnych dla obu historiografii. Jednak interpretacyjnie jest to sytuacja dość skomplikowana, ponieważ temat został usytuowany na wysokim „stopniu epistemologicznym”, który dla autora oznacza złożoną perspektywę oglądu rzeczywistości. O ile analizowani dziewiętnastowieczni historycy polscy i niemieccy znajdują się głównie na pierwszym stopniu epistemologicznym, o tyle Kożuchowski jako historyk historiografii, opisujący praktykę tworzenia obrazu dziejów w postaci ich narracji historycznej sytuuje się jako interpretator prac historycznych na drugim stopniu (tak jest w przypadku, gdy wykorzystuje tzw. „źródła pomocnicze i opracowania sprzed 1920 roku”) $)^{16}$. Autor pracy aktywny jest także na trzecim stopniu epistemologicznym, na którym budowana jest jego autorska interpretacja prac historiograficznych. Ta złożona perspektywa poznawcza wymagała uwzględnienia aż trzech rzeczywistości historyczno-kulturowych.

Po pierwsze, zróżnicowanej rzeczywistości historycznej XIX w., w której historycy tworzyli swoją narrację historyczną odnoszącą się do przeszłości Rzeczypospolitej lub Rzeszy, z uwzględnieniem specyfiki polityczno-kulturowej danego momentu tego stulecia, a także do ówczesnego stanu rozwoju wiedzy historycznej oraz wcześniejszej tradycji, którą historycy ci kontynuowali, albo z którą polemizowali (np. Lelewel, Schmitt, Szujski, Bobrzyński, Leo, Ranke, Stacke, Jastrow i inni).

14 Szerzej na temat paraleli Lelewelowskiej: V. Julkowska, Retoryka w narracji historycznej Joachima Lelewela, Poznań 1998.

15 A. Kożuchowski, Powinowactwa, s. 10.

16 Tamże, s. 246-247. 
Po drugie, rzeczywistości końca XIX i początku XX wieku, kiedy kształtowały się poglądy indywidualne historyków i powstawały nowe nurty oraz szkoły historyczne, tworząc własne podejścia historyczno-historiograficzne i odmienne oceny metodologiczne wcześniejszej historiografii (np. Bobrzyński, Smoleński; Konopczyński, Szelągowski, Kochanowski, Bujak, Dembiński, Droysen, Mommsen, Lamprecht i in.). W części analizowanych tekstów historyczno-historiograficznych występuje również odniesienie krytyczne do tradycji historiograficznej doby romantycznej lub tradycji późniejszej, pozytywistyczno-faktograficznej, dokonane przez autora z perspektywy zmian zachodzących w nauce historycznej.

Po trzecie, rzeczywistości historyczno-historiograficznej współczesnej autorowi pracy, która współtworzy jego własną perspektywę badawczą i teoriopoznawczą, dostarczając metod i narzędzi badania historiografii z najszerzej ujmowanych obszarów humanistyki w ujęciu bliskim zarówno strukturalistycznym jak i postrukturalistycznym.

Poszukując źródeł zainteresowania Kożuchowskiego metodą paraleli, można wskazać, iż ma on na swoim koncie badanie problemów analizy i interpretacji narracji historycznej, które sprzyjają stałemu rozszerzaniu pola obserwacji tekstów historiograficznych o nowe wymiary interpretacyjne, w tym także o poszukiwanie czysto literaturoznawczych albo retorycznych inspiracji do celów związanych z analizą narracji historycznej. Mam tu na myśli zainteresowania autora problemem tzw. scenariuszy alternatywnych, które już wcześniej ujmowane były przez J. Topolskiego w jego metodologii jako zdania kontrfaktyczne.

$\mathrm{Z}$ analizy pracy Kożuchowskiego wyłania się istotny problem natury metodologicznej, który moim zdaniem tkwi w tym, że zagadnienia dostrzeżone w pracach historyków XIX wieku posłużyły autorowi jako nadrzędne osie porządkujące jego własną narrację. Chodzi o tytuły rozdziałów (np. „Natura i charakter”, „Zenit”, „Zmierzch i upadek”, „Nigdy nie jest za późno” itp.), które określone przez autora mianem „obszarów analogicznych ujęć", interpretuję raczej jako zabiegi na poziomie problematyzacji licznej reprezentacji tekstów oraz na poziomie konstrukcyjnym pracy.

Bez szczegółowego podejścia analitycznego do tekstów historyków, czyli bez uchwycenia ich historyczności i różnych perspektyw metodologicznych, uwagi podsumowujące wypadają zbyt arbitralnie. Za szczególnie ryzykowne można uznać umieszczanie w jednym ciągu kilku historyków o różnych poglądach na rzeczywistość i budowanie na tej podstawie nieróżnicującej opinii. Komparatystyka jako rodzaj kompetencji wymaga bowiem bezwzględnego wlączenia do praktyki interpretacyjnej wiedzy teoretycznej. Bez wskazania na wybrane podstawy teoretyczne i konteksty interpretacji uwagi interpretacyjne zdają się bazować wyłącznie na subiektywnej 
lekturze dzieł. Autor przygotowując nową syntetyzującą narrację ma prawo do dystansowania się względem stanowisk dawnych historyków historiografii, jednak powinno towarzyszyć temu zabiegowi formułowanie własnego stanowiska teoriopoznawczego oraz jednoczesne tworzenie metapoziomu własnej pracy. W przeciwnym razie autor zatrzymuje się na poziomie treści pochodzących z interpretowanych przez siebie prac historycznych i nie wychodząc w komentarzu poza te treści. Mimo bogatej bibliografii przedmiotu w pracy Kożuchowskiego zabrakło odniesienia do powstałych w XXI wieku prac polskich historyków historiografii, których dyskursywne podejście do poruszanych przez autora problemów narracji historycznej i jej interpretacji byłoby co najmniej przydatne (np. Bugajewski, Dolański, Domańska, Julkowska, Malczewska, Pawelec, Pomorski, Topolski, Werner, Wrzosek, Zalejko, Zamorski).

Niewątpliwie jednak praca Kożuchowskiego jest rodzajem wartościowej autorefleksji na temat uprawianej dziedziny badań, a z uwagi na przyjęte założenia ma charakter rzadko podejmowanej porównawczej analizy oraz interpretacji dokonanej w obszarze historii historiografii. Książka zawiera rozpoznania, które ukazują w nowym świetle obraz niezależnie powstających narracji historycznych w obrębie historiografii polskiej i niemieckiej, jako w wielu obszarach analogiczny, nie wprost jednak, lecz właśnie na wyższym poziomie epistemologicznym.

\section{PARALELA NA POGRANICZU HISTORII HISTORIOGRAFII 1 LITERATUROZNAWSTWA}

Publikacja autorstwa Danuty Zawadzkiej zatytułowana: Mickiewicz i Lelewel. Paralela ${ }^{17}$ powstała $w$ kręgu współczesnych badań literaturoznawczych, prowadzonych w duchu badań „kulturowej historii literatury” postulowanych przez Ryszarda Nycza ${ }^{18}$. Książka Zawadzkiej stwarza możliwość unikalnego wglądu w teksty historyczne Lelewela i Mickiewicza, twórców dwóch wielkich polskich narracji - gminowładczej i mesjanistycznej - kluczowych dla narodowego dyskursu w XIX wieku.

Unikalność podejścia wynika z faktu podjęcie przez autorkę wyzwania jakim była równoległa lektura oraz interpretacja pisarstwa historycznego Joachima Lelewela i tekstów o historii Adama Mickiewicza, pochodzących z lat 1815-1833. Całość została poprzedzona istotnym założeniem badawczym o paralelnym ujęciu interpretacji, ale z jednoczesnym poszanowaniem autonomii dziedzin, które owe teksty reprezentują. Założenie to postawiło przed autorką, która jest badaczką historii literatury i literatu-

17 D. Zawadzka, Lelewel i Mickiewicz. Paralela, Białystok 2013, s. 9-11.

18 R. Nycz, Możliwa historia literatury, [w: ] Na pograniczach literatury, red.J. Fazan, K. Zajas, Kraków 2012, s. 32. 
roznawczynią, dodatkowe zadanie polegające na kompetentnym odnajdywaniu się w polu badań historycznych i historiograficznych.

Dodajmy, że było to zadanie tym trudniejsze, że wykraczające poza współczesną recepcję prac Lelewela i Mickiewicza, która poza kilkoma wyjątkami, biegnie od lat nurtami osobnymi ${ }^{19}$.

Postawa metodologiczna autorki ujawniła się od pierwszych stron pracy w wyborze określonych praktyk badawczych właściwych dla wspomnianej wyżej kulturowej teorii literatury, a z drugiej dla „nowego historycyzmu” S. J. Greenblata ${ }^{20}$. Kluczowe w interpretacji tekstów są zwłaszcza jego kategorie: rezonansu i zachwytu. Ich twórcze zastosowanie podczas lektury tekstów Mickiewicza i Lelewela, polegało na wydobyciu historycznych okoliczności ich pojawienia się i odbioru. „Rezonans” danego tekstu odczytany został przez autorkę jako jego zdolność do wykraczania poza formalne granice oraz wyzwalania u odbiorcy złożonych, dynamicznych sił kulturowych, z których się ów przedmiot wyłonił. Natomiast „zachwyt” został odczytany jako umiejętność przykuwania uwagi i przekazywania sensu niepowtarzalności ${ }^{21}$.

Potencjalna trudność podjętego zadania polegała w pierwszej kolejności na tematyzacji ambitnego problemu badawczego, w którym centralną rolę odgrywają dwaj kluczowi dla XIX stulecia twórcy, a przy tym kontrowersyjni, co obarcza tego typu badania niezwykle rozległym kontekstem towarzyszących wypowiedzi krytycznych i polemicznych innych autorów, których nie sposób przy tej okazji pominąć. Rozwiązaniem okazała się decyzja o przygotowaniu kilku studiów przypadku, powiązanych chronologią i miejscem powstających dzieł obu autorów. Autorka w kolejnych studiach („Skandynawia”, „Wilno 1822”, „Litwa”, „Imperium”, „Historia i pamięć”) wykorzystuje doświadczenie analityczne badań komparatystycznych, centro-peryferyjnych, narratywistycznych i pamięcioznawczych.

Dużo większym wyzwaniem okazał się wybór metodologiczny, jakiego dokonała autorka sięgając po paralelę, potraktowaną jako metoda interpretacji porównawczej na pograniczu dyscyplin, przy zachowaniu ich autonomii. Podejście interdyscyplinarne w zależności od rodzaju analizowanych tekstów wymagało jasnego określania i stale obecnej świadomości w jakim zakresie występuje w pracy i jak jest rozumiane podejście historyczne i literackie. Czerpanie z doświadczeń zwrotu narratywistycznego tylko w niewielkim stopniu niwelowało trudności, wynikające z porównawczej analizy tekstów historycznych i literackich.

19 Por.: D. Zawadzka, Paralela recepcji. Lelewel i Mickiewicz w odbiorze literaturoznawców i historyków, „Sensus Historiae. Studia interdyscyplinarne" 2014, nr 2.

20 R. Nycz, Możliwa historia literatury, [w: ] Na pograniczach literatury, red. J. Fazan, K. Zajas, Kraków 2012, s. 32; S. Greenblatt, Poetyka kulturowa. Pisma wybrane, Kraków 2006, s. 157-193.

21 Tamże, s. 11. 
Nowatorstwo analizy i interpretacji oparte na przyjętym założeniu lektury równoległej, poprzedziła jasna deklaracja autorska, że praca została napisana z perspektywy historycznoliterackiej. Zatem historyczny charakter paraleli przejawiał się na poziomie konsekwentnego porządku chronologicznego porównywanych tekstów oraz w obszarze budowania szerokiego kontekstu historycznego. W ten sposób pole symboliczne literatury zostało wzbogacone o świadomość historyczną odnośnie historyczności analizowanych tekstów, zaś kontekst ich powstania o wymiar chronologiczny i spacjalny. Powstałe studium porównawcze piśmiennictwa Lelewela i Mickiewicza wykazuje jako całość tendencję do ukazywania hybrydycznego, historyczno-literackiego charakteru historyzmu, adekwatnego dla rozumienia kultury historycznej pierwszej połowy XIX, jak również kultury pogranicza.

Książka jest „historyczna” również na poziome koncepcyjnym, który autorka zawdzięcza ożywczej inspiracji praktyką twórcy „nowego historycyzmu” Greenblatta. Chodzi zwłaszcza o zastosowanie jego strategii wyprowadzania argumentów z uwarunkowań historycznych i lokalnych, wraz z założeniem, że stanowią one część subiektywnego, indywidualnego oglądu rzeczywistości ${ }^{22}$. Zamiarem autorki stało się więc uzyskanie efektu poznawczego i estetycznego, który ona sama określiła jako „wyzwolenie” w czytelniku złożonych dynamicznych sił kulturowych, pobudzających do myślenia historycznego oraz do jednoczesnego odczuwania przeżycia estetycznego.

Zawadzka sięgnęla również po inspirację do filozofów historii z kręgu narratywistycznego i postkonstruktywistycznego, a równoległe "czytanie” pisarstwa historycznego Joachima Lelewela i tekstów o historii Adama Mickiewicza, wymagało zaznajomienia się ze specyfiką przemian dokonujących się w obrębie historii, stopniowo konstytuującej się jako samodzielna dyscyplina badań naukowych, tworząca własny warsztat badawczy.

Zastosowanie paraleli jako metody badawczej zasługuje na szczególną uwagę, ponieważ jest w swym kształcie myślowym i kompozycyjnym nawiązaniem do tradycji ujęć porównawczych, chętnie stosowanych także przez Lelewela i Mickiewicza. Dla obu paralela była nie tylko analityczną metodą pracy, ale i sposobem myślowego oraz tekstowego uporządkowania refleksji. Metoda paraleli, zwłaszcza w przypadku prac Lelewela, okazywała się również doskonałym sposobem przezwyciężania oświeceniowej tradycji myślenia analogicznego poprzez myślenie paradoksalne. Lelewel nie zadowalając się odkrytymi podobieństwami, miał zwyczaj drążenia problemu, w jego złożoności i oryginalności, przez co wykazywał niepodważalną historyczność tej metody.

22 D. Zawadzka, Lelewel i Mickiewicz, s. 10. 
Próbą pogłębienia metodologicznego efektu paraleli są współczesne badania komparatystyczne, do których odwołuje się w swojej pracy Danuta Zawadzka. Dają one szansę na wskazanie obszarów wzajemnych relacji różnych dyscyplin humanistycznych, ponieważ prowadzone są z uwzględnieniem ich poziomu metakrytycznego. Autorka wypełniła ten warunek znakomicie, dzięki dobrej znajomości współczesnych dyskursów, obecnych w rozległym polu badań humanistycznych. Każdy z kolejnych rozdziałów stał się więc okazją do zaprezentowania w autorskiej praktyce pisarskiej możliwości interpretacyjnych, uruchomionych dzięki znajomości tych obszarów.

To właśnie na meta poziomie dyskursów dochodzi do uruchomienia perspektyw, które pozwalają dostrzec czytelnikowi owo wzajemne „poruszanie strun”, obecne w pracach Lelewela i Mickiewicza. Lektura paralelna ich tekstów sprawia, że to co wydawało się mało już dziś znaczące, zapomniane i nieobecne, odżywa z nową siłą.

W książce Danuty Zawadzkiej tytułowa paralela nabiera wielowymiarowego znaczenia, które wywodząc się z retorycznej tradycji porównania, zostaje przez autorkę umiejętnie przetworzone w nowoczesną metodę interpretacyjną. Paralela jako kategoria myślowa odnosi się zatem w pierwszym rzędzie do zamysłu hermeneutycznie pogłębionej analizy porównawczej prac historycznych Lelewela i Mickiewicza. Ponadto paralela występuje także w funkcji kategorii porządkującej sposób refleksji, założonej przez autorkę jako wieloperspektywiczne ujęcie problematyki badań. W końcu paralela staje się także punktem wyjścia do spójnego przedstawienia efektów krytycznej lektury równoległej tekstów historycznych, dokonanej przez autorkę.

Systematyczność przeprowadzonej paraleli, została uzyskana poprzez wyodrębnione siedmiu wątków problemowych, składających się na całość konstrukcyjno-kompozycyjną pracy.

Można odnieść wrażenie, że rozpoczynające książkę dwie części poświęcone zagadnieniom recepcji, biografii oraz stosowanej przez Lelewela i Mickiewicza terminologii, tworzą wraz z częścią ostatnią, dedykowaną historii i pamięci, swoistą metaramę tej książki, jakby jej dodatkowy, być może widoczny z perspektywy historyka historiografii, porządek myślowy. Autorka dwukrotnie, na rozpoczęcie i na zakończenie swojej pracy, prowadzi refleksję na temat dostrzeżonych w badaniu recepcji obu twórców miejsc pustych, pominiętych, zapomnianych, a przez to nieobecnych w świadomości zbiorowej. Znamienne jest to, że w odróżnieniu od zasygnalizowanych na początku problemów recepcji, uruchomiony w części końcowej dyskurs pamięci, nie tylko służy do interpretacji konkretnych tekstów, ale przenosi dyskusję na inny poziom refleksji syntetycznej. Dzięki temu dyskurs pamięci pozwala na powrót wątków już znanych, na nowo otwierając ich interpretację. 
Część pierwsza to wprowadzenie do złożonego problemu recepcji, który tradycyjnie znajduje swoje omówienie we wstępach prac, natomiast decyzją autorską znalazł swoje miejsce osobno zaakcentowane. Dokonując przeglądu paralelnych odczytań literaturoznawców i historyków, pochodzących z lat 1861-2011, autorka kierowała się chęcią uświadomienia czytelnikowi skali problemu, jakim są w badaniach komparatystycznych niezależnie i niezbieżnie prowadzone dyskursy przedstawicieli różnych dyscyplin: w tym przypadku historyków historiografii i literaturoznawców.

Z kolei próba zestawienia kluczowych momentów życia Lelewela i Mickiewicza, choć ujawniła wiele wspólnych punktów w ich biografiach, to jednak z całą mocą uświadomiła, że znacznie ważniejsze w przypadku interpretacji dokonywanych przez nich wyborów i postaw intelektualnych byly różnice $\mathrm{w}$ doświadczeniach pokoleniowych obu analizowanych autorów. Zatem punktem wyjścia tej pracy, a zarazem argumentem w pełni uzasadniającym konieczność jej podjęcia, jest z jednej strony niewspółmiernie zaawansowany stan badań poświęconych z osobna obu bohaterom książki, a z drugiej wyprowadzone z porównania ich biografii przekonanie o tym, że dopiero paralelne zestawianie zdarzeń z ich życia, przyjmowanych postaw i głoszonych poglądów, otwiera nowe przestrzenie interpretacyjne. $\mathrm{W}$ tej części, tak istotnej dla koncepcji całości, zostały wyznaczone główne węzły chronologiczne oraz symboliczne przestrzenie, którymi autorka akcentuje swoje podejście interpretacyjne. Rok 1848 wymieniony na zakończenie sięga poza ramy chronologiczne pracy, ale w sensie symbolicznym i narracyjnym stanowi jej doskonałe zamknięcie.

Problem występujących u Lelewela i Mickiewicza pojęć oraz metafor historiograficznych, wypełnia część drugą książki i prowadzi do ukazania sposobu w jaki historyk i poeta pojmują dzieje, historię i narrację historyczną, stanowiąc wprowadzenie do obszaru badań historycznych i historiografii przełomu XVIII i XIX wieku. Poruszanie się przez autorkę w gąszczu pojęć oraz próba ich „semantycznego opanowania” to doskonały przykład uważnej lektury współczesnych opracowań historycznych. Głównym przedmiotem rozważań autorki w oparciu o jej niezwykle rzetelną analizę tekstów Lelewela jest semantyka terminów „dzieje” i „historia” w ujęciu właściwym dla świadomości nowożytnej, lecz inspirowanym badaniami z nurtu pomodernistycznego, między innymi pracami Jerzego Topolskiego, Wojciecha Wrzoska, ale też Reinharta Kosellecka ${ }^{23}$.

W trzeciej części pojawił się wątek skandynawski obecny w pismach Lelewela z lat 1806-1828, pozostający w związku z jego polskim przekładem Eddy, a także romantyczną fascynacją religią i kulturą Północy w pismach Mochnackiego, upatrują-

23 Tamże, s. 123-187. 
cego w niej źródeł polskiej literatury narodowej. Zawadzka przypomniała znamienny dla dynamiki badań historycznych Lelewela udział w przedpowstaniowej debacie krytycznoliterackiej w roli krytycznego badacza historii, zdolnego do przedstawienia własnego rozumienia romantyczności ${ }^{24}$.

Część czwarta zatytułowana Wilno 1822, wiąże się z symboliczną datą powstania Ballad i romansów, przyjmowaną jako początek polskiego romantyzmu oraz z miejscem uniwersyteckich wykładów Lelewela czasów jego drugiej profesury. W szerokim kontekście historycznym przywołany został wiersz Mickiewicza Do Joachima Lelewela, wraz z bogatą refleksją wokół formuły historyzmu, rodzajem kontaktów z przeszłością oraz etosem pracy historyka. Zawadzka podejmuje się próby wyjaśnienia fenomenu popularności Lelewelowskiego ujęcia historii u Filomatów, odwołując się do estetycznego doświadczenia historycznego ${ }^{25}$.

W części piątej pojawia się jedna z najbardziej fundamentalnych w pracy Zawadzkiej interpretacji, mianowicie Mickiewiczowska Grażyna, widziana jako literacka wersja doświadczenia historycznego inspirowanego historyką Lelewela. Szerokie spektrum zagadnień związanych z Litwą otwiera refleksję interpretatorki na katalog problemów związanych z definiowaniem poczucia własnej tożsamości obecnym w pracach Lelewela i Mickiewicza. Zawadzka prowadzi swoje subtelne analizy w ślad za rozwijanymi przez obu bohaterów paraleli koncepcjami narodu, zmierzając od początkowej, jeszcze oświeceniowej fazy narodu politycznego, charakterystycznej dla, jak ją określa, „tożsamości wieloszczeblowej”, aż do zapowiedzi przemiany tej koncepcji w fazie etnicznego nacjocentryzmu, która rozwijać się będzie w już zmienionych warunkach politycznych rosyjskiego imperium (doświadczenie Mickiewicza) i później emigracji ${ }^{26}$.

Efekty tej przemiany odnajdziemy już w kolejnej szóstej części pracy, obejmującej chronologicznie okres po procesie filomatów. Kierunek interpretacji wyznaczają tu Lelewelowska synteza Dziejów Polski potocznie opowiedzianych, z rozwijanym przez historyka programem wychowania historycznego dzięki kulturze i historii, jak również Konrad Wallenrod Mickiewicza, przejmująco oddane przez Zawadzką jako „studium litewskiej tożsamości przenarodowionej”27.

Praca interpretacyjna autorki wiele zawdzięcza w tej części inspiracji dyskursu postkolonialnego, lecz z pewnością nie byłoby to ujęcie pełne, gdyby nie dodatkowy impuls jaki daje metoda paraleli. Zamiast statycznych i przewidywalnych ujęć otrzy-

24 Tamże, s. 239-280.

25 Tamże, s. 285-348.

26 Tamże, s. 363-430.

27 Tamże, s. 437-530. 
mujemy zaskakująco szeroki kontekst historyczny, który coraz to otwiera czytelnika na epokę i ludzi, pozwala głębiej rozumieć wypowiadane słowa. Narracja Zawadzkiej zaskakuje świeżością spojrzenia i pomysłowością w wyszukiwaniu kolejnych tropów i problemów godnych porównania. Autorka nie stroni przy tym od komentarzy wobec prac uznanych w ostatnim czasie za interesujące lub za kontrowersyjne, ale czyni to z dużą kulturą i znajomością problemu, starając się zająć własne stanowisko uzasadnione merytorycznie prowadzonymi badaniami.

Wspomnianą wcześniej ramę teoretyczną pracy, zapoczątkowaną w części pierwszej, zamyka dyskurs pamięci, który wcześniej zaledwie sygnalizowany, pojawia się z całą mocą perswazyjną na końcu pracy. Jest to dogodna okazja, by podkreślić raz jeszcze jak istotną rolę w poszukiwaniu wspólnych przestrzeni porozumienia odgrywają w interdyscyplinarnych badaniach komparatystycznych nowe dyskursy. W kolejnych częściach tej pracy byly one uruchamiane przez autorkę niezwykle adekwatnie do poruszanych zagadnień: od dyskursu narratywistycznego, przez postkolonialny, aż po wspomniany dyskurs pamięci. Instrumentarium pojęciowe i problemowe każdego z wymienionych dyskursów pozwala dostrzec szansę nie tylko na atrakcyjne poznawczo interpretacje prac Lelewela i Mickiewicza, lecz co ważniejsze, pozwala znacząco zbliżyć się ujęciom polonistycznym i historycznym. Łatwość i konsekwencja z jaką Zawadzka uruchamia w kolejnych częściach pracy wątki tematyczne i wskazuje na kluczowe problemy właściwe dla poszczególnych okresów działalności naukowej Lelewela oraz faz twórczości Mickiewicza, świadczy o jej interdyscyplinarnych kompetencjach oraz o dobrej orientacji w toczonych współcześnie na terenie humanistyki dyskusjach. Zamysł koncepcyjny i kompozycyjny pracy znalazł wyraz w rozszerzającej się perspektywie ujęcia interpretacyjnego poczynając od studium przypadku, poprzez perspektywę lokalną i regionalną aż do ujęcia spektrum kontynentalnego (rosyjskiego i europejskiego).

Mimo rozległości poruszanej problematyki Zawadzka interpretuje wybrane prace historyczne Lelewela i Mickiewicza w kategoriach adekwatnych dla poszczególnych dyskursów (np. w dyskursie pamięci są to: pamięć kulturowa, poetyka świadectwa, kultura pamięci $)^{28}$. Szczególnie widoczne jest zastosowanie doświadczeń, wynikających z lektury kluczowych tekstów, należących do dyskursu pamięci (np. J. Assmann, M. Halbwachs, K. Pomian) podczas analizy Nowosilcowa $w$ Wilnie Lelewela oraz III części Dziadów.

Autorka odczytuje teksty Lelewela i Mickiewicza jako świadectwa pamięci utrwalonej, a zatem już zmienionej w przekaz historyczny, co prowadzi ją do próby krytycznego przewartościowania poglądów na temat roli pamięci w literaturze roman-

28 Tamże, s. 535-600. 
tycznej w sposób polemiczny do ujęcia zaproponowanego przez Krzysztofa Trybusia ${ }^{29}$. Równoległa lektura jaką proponuje Zawadzka nie zadowala się przeciwstawieniem dyskursu historii i pamięci odpowiednio w pracach Lelewela i Mickiewicza, lecz zgodnie z zasadą rezonansu pogłębia temat, odkrywając skomplikowaną sieć wzajemnych relacji między tekstami. Dochodzi do zaskakująco wnikliwych i trafnych spostrzeżeń: jak choćby diagnoza osobistego dramatu Lelewela, który polegał na tym, że historykowi przyszło żyć w czasach, kiedy realizacja własnych pasji naukowych wydawała się egoistycznym luksusem.

Autorka interesująco omawiając trudne językowo i znaczeniowo teksty, zapewnia powrót do spraw zapomnianych lub pomijanych, podając je w formie interpretacyjnej, uwspółcześnionej poprzez odwołania do dyskursu pamięci. Paralela stwarza niepowtarzalną okazję do ponownego odczytania treści słabo dotąd rozumianych (np. Polska odradzająca się Lelewela w kontekście cz. III Dziadów).

\section{NA ZAKOŃCZENIE}

Obie analizowane prace prowadzą do wniosku, że paralela jako metoda i jednocześnie zamysł kompozycyjny pracy, w połączeniu z nowoczesnym instrumentarium literaturoznawczym, historiograficznym i kulturoznawczym staje się kreatywnym, a przy tym niezwykle inspirującym myślowo, sposobem zbudowania nowej perspektywy badawczej, nie tylko w odniesieniu do prac stricte historycznych, jak książka Kożuchowskiego, ale również na pograniczu historiografii i literatury, jak w przypadku pracy Zawadzkiej.

Znaczenie obu rozpraw wykracza poza kwestię zasygnalizowaną w tytułach, ponieważ można w nich dostrzec przykład badań nowego typu, wychodzących poza tradycyjny model stosowany w obszarach historii historiografii i historii literatury.

Postawienie i przekonujące rozwiązanie oryginalnych kwestii badawczych w trudnym ujęciu komparatystycznym wymaga poruszania się w gąszczu problemów własnej jak i pokrewnych dyscyplin, z jasną świadomością celu. Ponadto prace tego typu wymagają uważnych czytelników, którzy jednak w zamian otrzymują nowe interpretacje starych Mistrzów.

Wbrew dość powszechnym tendencjom do zawężania i zamykania dyscyplin badawczych w wąskich kanonach specjalizacji, prace komparatystyczne są przykładem twórczego łączenia różnych kompetencji na polu badań humanistycznych, zwłaszcza w odniesieniu do obszarów pogranicznych.

29 K. Trybuś, Pamięć romantyczna, Poznań 2010. 